\title{
Physical Fitness Level and Its Relationship with Self-Concept in School Children
}

\author{
Pedro L. Rodríguez García1,2, Loreto Tarraga Marcos ${ }^{1,2}$, Andrés Rosa Guillamón 1,2, \\ Eliseo García-Cantó 1,2, Juan J. Pérez-Soto1,2, Arancha Gálvez Casas ${ }^{1,2}$, Pedro Tarraga Lopez ${ }^{1,2}$ \\ ${ }^{1}$ Universidad de Murcia, Murcia (España), Spain \\ ${ }^{2}$ Universidad Castilla la Mancha, Albacete, Spain \\ Email: pjtarraga@sescam.jccm.es
}

Received 31 September 2014; revised 28 October 2014; accepted 19 November 2014

Copyright (C) 2014 by authors and Scientific Research Publishing Inc.

This work is licensed under the Creative Commons Attribution International License (CC BY). http://creativecommons.org/licenses/by/4.0/

(c) (i) Open Access

\begin{abstract}
Objectives: The purpose of this study was to analyze the relationship between general self-concept and health-related physical fitness in primary school children. Design: Cross-sectional design and descriptive court. Method: A total of 216 schoolchildren $(9.26 \pm 1.26$ years) participated in the measurement of the speed-agility, muscle strength and aerobic capacity as physical fitness components. Six dimensions of self-concept (intellectual, behavioral, physical, lack of anxiety, social and life satisfaction) were assessed by the Self-Concept Scale Piers-Harris. Results: No significant differences were found among the self-concept dimensions between men and women. Males showed higher scores on the test of $4 \times 10 \mathrm{~m}(p<0.05)$, manual dynamometry $(p<0.005)$ and Course-Navette $(p<0.005)$. An increased fitness level was positively and significantly related with higher values of overall self-concept $(p<0.005)$ in both genres. Conclusion: The results of this study suggest that those students with a higher overall fitness level show higher levels of general self-concept. More investigation is needed to know which physical fitness parameters are more related with the self-concept.
\end{abstract}

\section{Keywords}

Health, Physical Fitness, Self-Concept, Physical Activity, Childhood

\section{Introduction}

Self-concept is one of the most analyzed health-related psychological constructs (Madariaga \& Goñi, 2009). One of the most important conceptual approaches on self-concept (Shavelson, Hubner, \& Stanton, 1976) defined it as the perceptions that the individual has about himself, which are based on his experiences with others, inte-

How to cite this paper: García, P. L. R., Marcos, L. T., Guillamón, A. R., García-Cantó, E., Pérez-Soto, J. J., Casas, A. G., \& Lopez, P. T. (2014). Physical Fitness Level and Its Relationship with Self-Concept in School Children. Psychology, 5, $2009-2017$. http://dx.doi.org/10.4236/psych.2014.518204 
raction with the environment, and the attributions that he makes of his own behavior.

Adequate perception, organization and integration of experiences on dimensions of self-concept has been a multidimensional nature factor of particular importance for adequate standards of conduct, performance and development in several areas of personality (Esnaola, Goñi, \& Madariaga, 2008).

Childhood and adolescence are critical periods for positive development of self-concept due to major physical, cognitive and social changes that occur during these life stages (Demo \& Savin-Williams, 1992; Harter, 1999; Cardenal \& Fierro, 2003).

Over the last few years, different studies have related self-concept in young people with several factors such as socioeconomic status (Aktop, 2010), body weight (Willows, Ridley, Raine, \& Maximova, 2013), academic performance (Agarwall, Bhalla, Kaur, \& Babbar, 2013), motor coordination (Vedul-Kjelsås, Sigmundsson, Stensdotter, \& Haga, 2012), physical activity (Cooke, Trebaczyk, Harris, \& Wright, 2014), sport participation (Slutzky \& Simpkins, 2009) or physical fitness (Guillén \& Ramírez, 2011).

Physical fitness is an integrated measure of all functions (psycho-neurological, musculoskeletal, cardio-respiratory, blood-circulatory and endocrine-metabolic) and structures involved in the individual physical activity (Ruiz, España Romero, Castro Piñero, Artero, Ortega et al., 2011). It has been found that the level of physical fitness is an important biomarker of overall health since childhood (Ortega, Ruiz, Castillo, \& Sjostrom, 2005).

Among those studies that have specifically examined the association between physical fitness and self-concept among young, a healthy physical condition had been linked with higher levels of self-concept (GarcíaSánchez, Burgess-Mengibar, Lopez-Blanco, \& Ortega, 2013). Other studies have also linked several parameters of physical fitness with self-concept in primary schoolchildren (Folsom-Meek, 1991; Overbay \& Purath, 1997), and physical self-concept in adolescents (Aşç1, 2003; Carraro, Scarpa, \& Ventura, 2010; Contreras, Fernández, García, Palou, \& Ponseti, 2010) obtaining positive and significant relationship between the two variables.

Intervention programs to improve physical fitness have shown positive impact in psychological variables such as self-concept and self-esteem in studies with samples from different countries (Weiss, McAulley, Ebbeck, \& Wiese, 1990; Planinsec \& Fosnaric, 2005; Moreno, Moreno, \& Cervelló, 2007; Altintaş \& Aysçi, 2008; Beets, Beighle, Erwin, \& Huberty, 2009; Cumming, Standage, Loney, Gammon, Neville et al., 2011).

Knowing the importance of developing an appropriate healthy fitness condition and the studies that suggest a possible link with self-concept among young people, which has been described that affects the quality of life and psychosocial well-being by itself, the objective of this study was to analyze the relationship between general self-concept and physical fitness, measured through the ALPHA-school Fitness Battery, among Spanish children from several elementary schools.

We hypothesized that participants with higher physical fitness level would report an increased general selfconcept in multiple domains as a casual relationship. However, it has not clearly been shown in the literature among subjects of this age range.

\section{Materials and Methods}

\subsection{Participants}

A total of 216 Spanish students (91 men and 125 women) aged between 8 and 11 years (mean \pm SD: $9.26 \pm 1.26$ years) participated in this cross-sectional study and descriptive court. As exclusion criteria in the study was established the presence of chronic diseases or bone-muscular and cardiovascular risk.

The study was conducted in accordance with the ethical standards recognized by the Declaration of Helsinki (Hong Kong revision, 1989), and following the recommendations of Good Clinical Practice of the EEC (document 111/3976/88 July 1990 ) and current Spanish legislation governing clinical research in humans (Royal Decree 561/1993 on clinical trials). This work has been submitted for examination and has obtained the approval of the Bioethics Committee of the University of Murcia (Table 1).

\subsection{Measures}

\subsubsection{The ALPHA-Fitness Battery Evidence Based (Ruiz et al., 2011)}

The aptitude of the participants to perform the fitness test was obtained through the Readiness Questionnaire Physical Activity (Thomas, Reading, \& Shepard, 1992). To measure the fitness level several tests were chosen from the ALPHA-Fitness Battery evidence based (Ruiz et al., 2011). Furthermore, the speed-agility test $4 \times 10$ 
Table 1. Sample described by sex and age.

\begin{tabular}{|c|c|c|c|c|c|c|c|}
\hline & & \multicolumn{6}{|c|}{ Age } \\
\hline & & & 8 & 9 & 10 & 11 & Total \\
\hline \multirow{6}{*}{ Sex } & \multirow{3}{*}{ Males } & Count & 22 & 14 & 16 & 39 & 91 \\
\hline & & Sex \% & $24.2 \%$ & $15.4 \%$ & $17.6 \%$ & $42.9 \%$ & $100.0 \%$ \\
\hline & & Total \% & $10.2 \%$ & $6.5 \%$ & $7.4 \%$ & $18.1 \%$ & $42.1 \%$ \\
\hline & \multirow{3}{*}{ Females } & Count & 35 & 25 & 12 & 53 & 125 \\
\hline & & Sex \% & $28.0 \%$ & $20.0 \%$ & $9.6 \%$ & $42.4 \%$ & $100.0 \%$ \\
\hline & & Total \% & $16.2 \%$ & $11.6 \%$ & $5.6 \%$ & $24.5 \%$ & $57.9 \%$ \\
\hline \multirow{3}{*}{ Total } & & Count & 57 & 39 & 28 & 92 & 216 \\
\hline & & Sex \% & $26.4 \%$ & $18.1 \%$ & $13.0 \%$ & $42.6 \%$ & $100.0 \%$ \\
\hline & & Total \% & $26.4 \%$ & $18.1 \%$ & $13.0 \%$ & $42.6 \%$ & $100.0 \%$ \\
\hline
\end{tabular}

meters with the purpose of obtaining more complete information in motor capacity and general dynamic coordination was added.

The maximum hand grip strength was measured by maximum hand dynamometry using a digital dynamometer with adjustable grip (TKK 5041 Grip D, Takei, Tokyo, Japan), and a rule-table to adjust the amplitude of the grip (España-Romero et al., 2010). The explosive lower body strength was assessed by longitudinal jump with feet together (Castro-Piñero et al., 2010). The speed and agility was estimated with the $4 \times 10$ meters test (Vicente-Rodríguez et al., 2012). Aerobic capacity was evaluated through the 20-meter test return (Leger, Mercier, Gadoury, \& Lambert, 1988).

To relate this variable with the self-concept, an average of the participants scores was established according to their performances in each fitness test (test 20 meter test of $4 \times 10$ meters, grip strength and longitudinal jump) resulting in an overall score that framed the subjects in low, moderate or high fitness. All the tests had reliability coefficients R intraclass between 0.95 and 0.99 for intra-explorer measures and between 0.98 and 0.99 for inter-explorer measures. Similarly, validity were positive inter and intra-explorer in the four tests, being a great variability between the records, no significant differences were found in the intra-case measures.

\subsubsection{Self-Concept Scale Piers-Harris (Piers \& Harris, 1984)}

The general self-concept was assessed using the Self-Concept Scale Piers-Harris (Piers \& Harris, 1984), specifically designed for students aged 7 to 12 years. This questionnaire was adapted by Cardenal and Fierro (2003) and is one of the most comprehensive and valuable for schools. This scale consists of 80 items formulated in simple sentences and dichotomous nature (Yes/No), which indicate the degree of agreement or disagreement with the statement of the item. The scale measures the individual's perception of himself (General Self-concept), and how to assess a number of aspects of their personality and behavior, according to the following dimensions:

a) Conduct-Behavior (18 items). Describe the extent to which the school admits or denies problematic behavior.

b) Intellectual and Academic Status (17 items). Reflects the child self-worth in relation to homework, including a general feeling towards the school.

c) Physical Appearance (12 items). Poses attitudes regarding physical characteristics, and issues such as leadership and ability to express their ideas.

d) Lack of Anxiety (12 items). Describe comprises an altered mood and concerns relating to various emotions, nervousness, sadness or fear.

e) Social or Popularity Scale (12 items). It measures how the school values its popularity and acceptance among their peer group.

f) Happiness-Satisfaction (9 items). It reflects a general feeling of being happy and satisfied with life.

High scores on the subscales correspond to a positive self-concept, except for the anxiety sub-scale in which higher scores reflect lower levels of anxiety. The psychometric properties of this scale have been documented in 
numerous studies showing adequate internal consistency and high reliability and validity (Piers, 1984).

The scale was subjected to confirmatory factor analysis determined the grouping of the items in the 6 factors listed above.

The three factors explain a variance of $78.95 \%$ of the total, reaching acceptable levels for these tests.

Psychometric analysis and study of reliability was performed on the 80 items that composed the scale. To calculate the overall reliability of the scale was implemented the classical procedure by Cronbach (Martinez Arias, 1995), obtaining an overall value of 0.86 .

\subsection{Procedures}

The study was conducted during school hours and with parental consent and school approval. Participants were evaluated by two investigators, providing examples of each test before rating them, using the same order to measure and leaving 5 minute intervals between measurements. The tests were presented in the same order in which they were conducted. The Self-Concept Scale Piers Harris was administered in groups of 20 to 25 students in a room that allowed a sufficient physical separation for privacy. There was an investigator in the room to solve any doubts and check that were completed properly. The questionnaire was completed during the morning with an average duration of 45 minutes.

\subsection{Data Analysis}

Descriptive statistics was used to obtain numerical and percentage counts by sex and age of the sample. In continuous variables has been reflected the mean and standard deviation. Inferential statistic was developed using analysis of variance (ANOVA). For the realization of the relationships mentioned has been used SPSS 18.0 for Windows.

\section{Results}

In Table 2, it is shown descriptive data for the different subscales of the general self-concept and the overall value of the overall scale considering gender and age. Mean comparisons were made by gender and age showed no significant differences in any of the self-concept dimensions and overall scale score.

Table 3 shows descriptive analysis assessing physical fitness measured by the ALPHA-Fitness Battery considering sex and age. The mean comparison with regard to sex shows significant differences in the 20-meter tests $(\mathrm{t}=3.44, p<0.005), 4 \times 10$ test $(\mathrm{t}=-2.44, p<0.05)$ and handgrip strength $(\mathrm{t}=2.89, p<0.005)$.

The analysis of variance relating the fitness levels and general self-concept values indicates that the increase of fitness level is positively and significantly related with higher values of overall self-concept $(p<0.005)$ (Table 4). The post-hoc analysis shows differences in fitness score almost 8 points between low and high $(p<$ $0.001)$.

\section{Discussion}

This study linked physical condition with the general self-concept and the sex differences among children between 8 and 11 years old.

Descriptive results corresponding to the different subscales of self-concept showed no statistically significant differences between men and women, although it is observed that males score slightly higher than women on all subscales, except in behavioral self-concept, lack of anxiety and happiness or satisfaction. In one of the few studies conducted with elementary school students (Guillén \& Ramirez, 2011) found no significant differences between the different constructs of self-concept in Spanish schoolchildren. The authors mentioned that their results may be due to the theory of development, stating that at that age have not yet consolidated self-concept. Another study with 1527 Spanish subjects between 10 and 11 years (Zulaika \& Goñi, 2000) also found significant relationships between men and women in the dimensions of physical self-concept and general self. Similarly, gender differences in perceived physical self-concept were found in a study with a sample of 364 boys and girls Slovenes (Planinsec \& Fosnaric, 2005).

Among adolescents, the trend is different as the literature clearly describes that there is significant sex differences in the different dimensions of self-concept (Jacobs, Lanza, Osgood, Eccles, \& Wigfield, 2002; Moreno \& Cervello, 2005; Videra-García \& Vidal-Garrido, 2013). 
Table 2. Self-concept global means by sex and age.

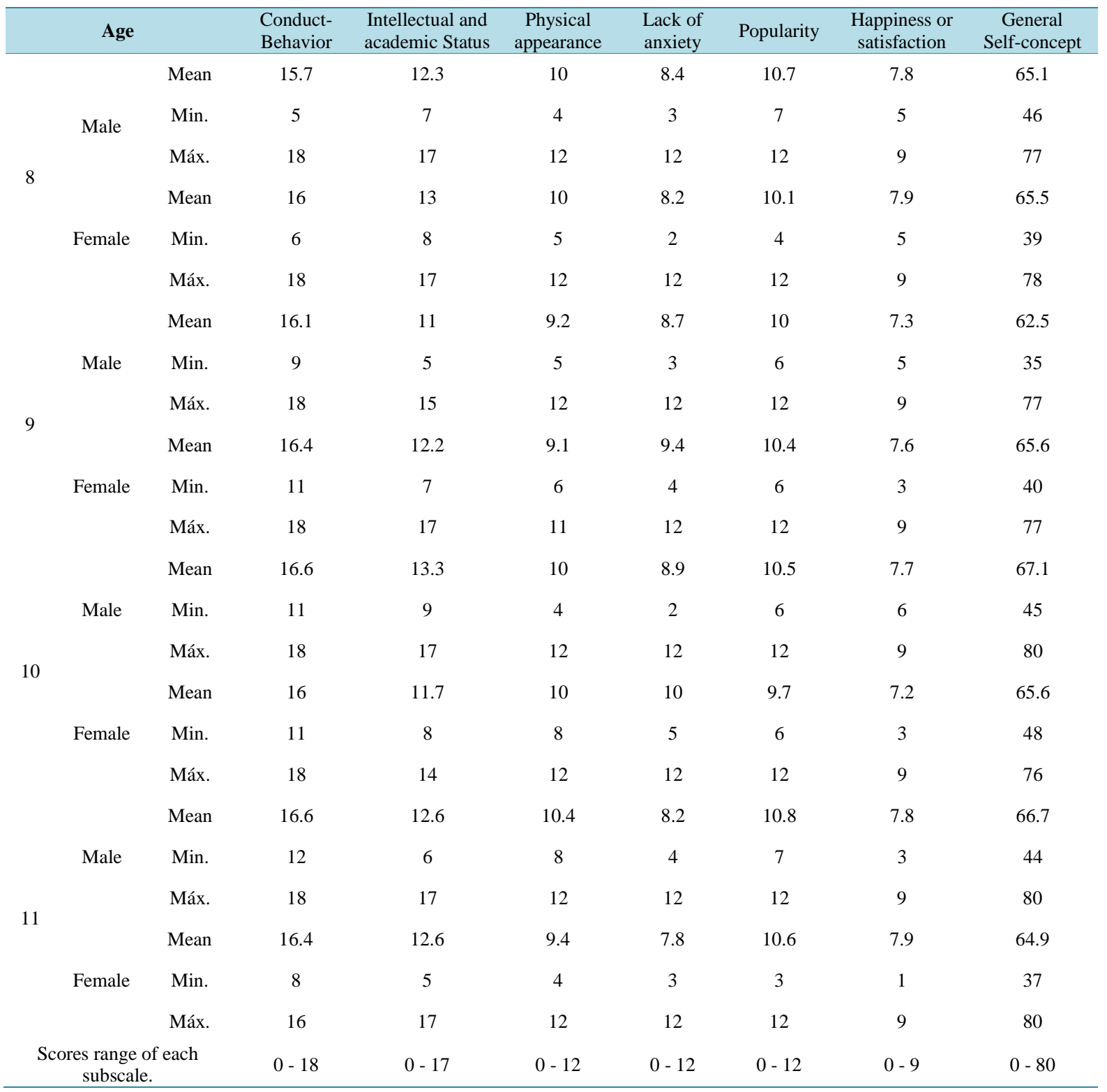

Regarding the physical condition, our study shows how men achieve better scores than women in all tests, except in the $4 \times 10$ meter agility test. This finding is consistent with other study (Guillén \& Ramirez, 2011) where males scored higher values of speed, strength and endurance than women. In another study (García-Sánchez et al., 2013) males performed better than women, in the agility test, hand grip strength and VO2max, being similar to the results of the present investigation.

Our results showed that the increase of the fitness level was significantly related to higher values of general self-concept. Similar findings were found in a study with a sample of 61 American children (Overbay \& Purath, 1997), the results showed positive relationships between self-concept and regular exercise as well as the number of abdominal crunches performed. In a study with schoolchildren aged between 9 and 12 years old in North America (Mitchell, Moore, \& Rudasill Bibeau, 2012) the subjects with a good level of fitness had higher selfconcept than those with a low level. In adolescents (Moore, Mitchell, Bibeau, \& Bartholomew, 2011) found significant improvements in all the self-concept constructs after finishing an exercise program with the purpose of increasing the endurance fitness. Another study with American female adolescents (Schneider, Dunton \& Coop- 
Table 3. Physical Fitness global means by sex and age.

\begin{tabular}{|c|c|c|c|c|c|c|}
\hline \multicolumn{3}{|c|}{ Age } & $20 \mathrm{~m}$ Test & $4 \times 10 \mathrm{~m}$ Test & Handgrip strength & Longitudinal jump \\
\hline \multirow{6}{*}{8} & \multirow{4}{*}{ Male } & Mean & 2.5 & 13.9 & 18.9 & 92 \\
\hline & & Min. & 1 & 12.3 & 8 & 67 \\
\hline & & Máx. & 6.6 & 16.7 & 31.5 & 123 \\
\hline & & Mean & 2.4 & 14.5 & 15.1 & 89.5 \\
\hline & \multirow[t]{3}{*}{ Female } & Min. & 1 & 12.9 & 6.6 & 54 \\
\hline & & Máx. & 4.3 & 18.4 & 28.8 & 127 \\
\hline \multirow{6}{*}{9} & & Mean & 2.7 & 13.6 & 15.6 & 96.8 \\
\hline & \multirow[t]{3}{*}{ Male } & Min. & 1.9 & 12 & 11 & 67 \\
\hline & & Máx. & 5.6 & 14.6 & 21.5 & 120 \\
\hline & & Mean & 2.5 & 13.9 & 13.4 & 94.6 \\
\hline & \multirow[t]{3}{*}{ Female } & Min. & 1.4 & 12.7 & 9 & 60 \\
\hline & & Máx. & 5.4 & 15.6 & 21 & 140 \\
\hline \multirow{6}{*}{10} & & Mean & 3.7 & 13.3 & 16.9 & 107.6 \\
\hline & \multirow[t]{3}{*}{ Male } & Min. & 1 & 12 & 9 & 80 \\
\hline & & Máx. & 6 & 15 & 25.4 & 142 \\
\hline & & Mean & 3.1 & 13.9 & 16.6 & 100.9 \\
\hline & \multirow[t]{3}{*}{ Female } & Min. & 1.7 & 12.7 & 12.5 & 82 \\
\hline & & Máx. & 5.2 & 15.4 & 21 & 122 \\
\hline \multirow{6}{*}{11} & & Mean & 4.8 & 12.8 & 20.5 & 112.3 \\
\hline & \multirow[t]{2}{*}{ Male } & Min. & 0.7 & 11 & 13 & 65 \\
\hline & & Máx. & 8.9 & 18 & 30 & 144 \\
\hline & \multirow{3}{*}{ Female } & Mean & 3.5 & 13.1 & 19.4 & 109.1 \\
\hline & & Min. & 1.3 & 10.5 & 11 & 64 \\
\hline & & Máx. & 7.7 & 15.87 & 30 & 185 \\
\hline
\end{tabular}

Note: Measurement units: 20 m test = 1 minute Paliers; $4 \times 10$ m Test = seconds; Handgrip strength = kilogrames; Longitudinal Jump = centimeters.

er, 2008) showed an increase in global physical self-concept among those participants who increased cardiovascular fitness after a 9-month physical activity program.

In another study with Italian adolescents (Carraro et al., 2010) was establish a link between the physical fitness, measured through EUROFIT battery, and the physical self-concept. In a longitudinal study with Spanish children (Mayorga-Vega, Viciana, Cocca, \& Wheel, 2012) used two weeks fitness program to observe the evolution of the physical self-concept. The experimental group showed no significant changes in physical selfconcept, while the scores of physical appearance, self-esteem and strength remained at the same level; however, the control group significantly decreased those values.

The study has certain limitations due to the cross-sectional design and its "ex post facto" design that does not establish a cause-effect relationship. The tests used for evaluating the fitness levels were field test which are unable to give the accurate precision of those test made in laboratory conditions. However, we used test widely validated that let us measure children from different Spanish elementary schools within the normal school schedule without interrupting in excess the normal course.

Considering the results of our study along with the studies shown, it may be confirmed that there is a consis- 
Table 4. Variance Analysis (ANOVA) relating the physical fitness level with general self-concept.

\begin{tabular}{|c|c|c|c|c|c|}
\hline \multicolumn{6}{|c|}{ General Self-Concept } \\
\hline & & $\begin{array}{c}\text { Mean of the Self-Concept } \\
\text { Scale }(0-10)\end{array}$ & \multicolumn{2}{|c|}{ Post-Hoc Differencies } & $p$-Value \\
\hline \multirow{6}{*}{ Physical Fitness } & \multirow{2}{*}{ Low } & \multirow{2}{*}{61.48} & Low-Moderate & -3.774 & .015 \\
\hline & & & Low-High & -7.784 & .000 \\
\hline & \multirow{2}{*}{ Moderate } & \multirow{2}{*}{65.26} & Moderate-Low & 3.774 & .015 \\
\hline & & & Moderate-High & -4.010 & .005 \\
\hline & \multirow{2}{*}{ High } & \multirow{2}{*}{69.27} & High-Low & 7.784 & .000 \\
\hline & & & High-Moderate & 4.010 & .005 \\
\hline
\end{tabular}

tent relationship between self-concept and physical fitness in young. This study reports that among children in elementary school the relationship also exists. There is no clear evidence of what parameters of physical fitness influence more to self-concept. Future studies with larger samples and focus on the effect of the different physical fitness areas on self-concept are needed to promote physical activity programs aims to improve those parameters.

\section{References}

Aşçı, F. H. (2003). The Effects of Physical Fitness Training on Trait Anxiety and Physical Self-Concept of Female University Students. Psychology of Sport and Exercise, 4, 255-264. http://dx.doi.org/10.1016/S1469-0292(02)00009-2

Agarwal, S., Bhall a, P., Kaur, S., \& Babbar, R. (2013). Effect of Body Mass Index on Physical Self Concept, Cognition \& Academic Performance of First Year Medical Students. Indian Journal of Medical Research, 138, 515-522.

Aktop, A. (2010). Socioeconomic Status, Physical Fitness, Self-Concept, Attitude toward Physical Education, and Academic Achievement of Children. Perceptual and Motor Skills, 110, 531-546. http://dx.doi.org/10.2466/pms.110.2.531-546

Altintaş, A., \& Aşçi, F. H. (2008). Physical Self-Esteem of Adolescents with Regard to Physical Activity and Pubertal Status. Pediatric Exercise Science, 20, 142-156.

Beets, M. W., Beighle, A., Erwin, H. E., \& Huberty, J. (2009). After-School Program Impact on Physical Activity and Fitness: A Meta-Analysis. American Journal of Preventive Medicine, 36, 527-537.

http://dx.doi.org/10.1016/j.amepre.2009.01.033

Cardenal, V., \& Fierro, A. (2003). Componentes y correlatos del autoconcepto en la escala de Piers-Harris. Estudios de Psicología, 24, 101-111. http://dx.doi.org/10.1174/021093903321329094

Carraro, A., Scarpa, S., \& Ventura, L. (2010). Relationships between Physical Self-Concept and Physical Fitness in Italian Adolescents. Perceptual and Motor Skills, 110, 522-530. http://dx.doi.org/10.2466/pms.110.2.522-530

Castro-Piñero, J., Ortega, F. B., Artero, E. G., Girela-Rejon, M. J., Mora, J., Sjostrom, M., \& Ruiz, J. R. (2010). Assessing Muscular Strength in Youth: Usefulness of Standing Long Jump as a General Index of Muscular Fitness. Journal of Strength and Conditioning Research, 24, 1810-1817. http://dx.doi.org/10.1519/JSC.0b013e3181ddb03d

Cumming, S., Standage, M., Loney, T., Gammon, C., Neville, H., Sherar, L. B., \& Malina, R. M. (2011). The Mediating Role of Physical Self-Concept on Relations between Biological Maturity Status and Physical Activity in Adolescent Females. Journal of Adolescence, 34, 465-473. http://dx.doi.org/10.1016/j.adolescence.2010.06.006

Contreras, O. R., Fernández, J. G., García, L. M., Palou, P., \& Ponseti, J. (2010). El autoconcepto físico y su relación con la práctica deportiva en estudiantes adolescentes. Revista de Psicología del Deporte, 19, 23-39.

Cooke, R., Trebaczyk, H., Harris, P., \& Wright, A. J. (2014). Self-Affirmation Promotes Physical Activity. Journal of Sport \& Exercise Psychology, 36, 217-223. http://dx.doi.org/10.1123/jsep.2013-0041

Demo, D. H., \& Savin-Williams, R. C. (1992). Self-Concept Stability and Change during Adolescence. In R. P. Lipka, \& T. M. Brinthaupt (Eds.), Self-Perspectives across the Life Span (pp. 116-150). Albany: State University of Nueva York Press.

Esnaola, I., Goñi, A., \& Madariaga, J. M. (2008). El autoconcepto: Perspectivas de investigación. Revista de Psicodidáctica, 13, 179-194.

España-Romero, V., Ortega, F. B., Vicente-Rodríguez, G., Artero, E. G., Rey, J. P., \& Ruiz, J. R. (2010). Elbow Position Affects Handgrip Strength in Adolescents: Validity and Reliability of Jamar, Dynex, and Tkk Dynamometers. Journal of Strength and Conditioning Research, 24, 272-277. http://dx.doi.org/10.1519/JSC.0b013e3181b296a5

Folsom-Meek, S. L. (1991). Relationships among Attributes, Physical Fitness, and Self-Concept Development of Elementary 
School Children. Perceptual and Motor Skills, 73, 379-383. http://dx.doi.org/10.2466/pms.1991.73.2.379

García-Sánchez, A., Burgueño-Menjibar, R., López-Blanco, D., \& Ortega, F. B. (2013). Condición física, adiposidad y autoconcepto en adolescentes. Estudio piloto. Revista de Psicología del Deporte, 22, 453-461.

Goñi, A., \& Zulaika, L. M. (2000). La participación en el deporte escolar y el autoconcepto en escolares de 10 a 11 años en la provincia de Guipúzcoa. Apunts, 59, 6-10.

Guillén, F., \& Ramírez, F. (2011). Relación entre el autoconcepto y la condición física en alumnos del Tercer Ciclo de Primaria. Revista de Psicología del Deporte, 20, 45-49.

Harter, S. (1999). The Construction of the Self. A Developmental Perspective. New York: Guilford Press.

Jacobs, J. E., Lanza, S., Osgood, D. W., Eccles, J. S., \& Wigfield, A. (2002). Changes in Children’s Self-Competence and Values: Gender and Domain Differences across Grades One through Twelve. Child Development, 73, 509-527. http://dx.doi.org/10.1111/1467-8624.00421

Leger, L. A., Mercier, D., Gadoury, C., \& Lambert, J. (1988). The Multistage 20 Meters Shuttle Run Test for Aerobic Fitness. Journal of Sports Sciences, 6, 93-101. http://dx.doi.org/10.1080/02640418808729800

Madariaga, J., \& Goñi, A. (2009). El desarrollo psicosocial. Revista de Psicodidáctica, 14, 93-118.

Mayorga-Vega, D., Viciana, J., Cocca, A., \& De Rueda, B. (2012). Effect of a Physical Fitness Program on Physical Self-Concept and Physical Fitness Elements in Primary School Students. Perceptual and Motor Skills, 115, 984-996. http://dx.doi.org/10.2466/06.10.25.PMS.115.6.984-996

Mitchell, N. G., Moore, J. B., Bibeau, W. S., \& Rudasill, K. M. (2012). Cardiovascular Fitness Moderates the Relations between Estimates of Obesity and Physical Self-Perceptions in Rural Elementary School Students. Journal of Physical Activity y Health, 9, 288-294.

Moore, J. B., Mitchell, N. G., Bibeau, W. S., \& Bartholomew, J. B. (2011). Effects of a 12-Week Resistance Exercise Program on Physical Self-Perceptions in College Students. Research Quarterly Exercise Sport, 82, 291-301. http://dx.doi.org/10.1080/02701367.2011.10599757

Moreno, J. A., \& Cervelló, E. (2005). Physical Self-Perception in Spanish Adolescents: Effects of Gender and Involvent in Physical Activity. Journal of Human Movement Studies, 48, 291-311.

Moreno, J. A., Moreno, R., \& Cervelló, E. (2007). El autoconcepto físico como predictor de la intención de ser físicamente activo. Revista de Psicodidáctica y Salud, 17, 261-267.

Ortega, F. B., Ruiz, J. R., Castillo, M. J., \& Sjostrom, M. (2005). Physical Fitness in Childhood and Adolescence: A Powerful Marker of Health. International Journal of Obesity, 32, 1-11. http://dx.doi.org/10.1038/sj.ijo.0803774

Overbay, J. D., \& Purath, J. (1997). Self-Concept and Health Status in Elementary-School-Aged Children. Issues in Comprehensive Pediatric Nursing, 20, 89-101. http://dx.doi.org/10.3109/01460869709026880

Piers, E. V. (1984). Revised Manual for the Piers-Harris Children' Self-Concept Scale (2nd ed.). Los Angeles, CA: Western Psychological Services.

Planinsec, J., \& Fosnaric, S. (2005). Relationship of Perceived Physical Self-Concept and Physical Activity Level and Sex among Young Children. Perceptual and Motor Skills, 100, 349-353. http://dx.doi.org/10.2466/pms.100.2.349-353

Ruiz, J. R., España Romero, V., Castro Piñero, J., Artero, E. G., Ortega, F. B., Cuenca García, M. et al. (2011). Batería ALPHA-Fitness: Test de campo para la evaluación de la condición física relacionada con la salud en niños y adolescentes, Nutrición Hospitalaria, 26, 1210-1214.

Shavelson, R. J., Hubner, J. J., \& Stanton, J. C. (1976). Self Concept: Validation of Construct Interpretations. Review of Educational Research, 46, 407-441. http://dx.doi.org/10.3102/00346543046003407

Slutzky, C. B., \& Simpkins, S. D. (2009). The Link between Children’s Sport Participation and Self-Esteem: Exploring the Mediating Role of Sport Self-Concept. Psychology of Sport and Exercise, 10, 381-389. http://dx.doi.org/10.1016/j.psychsport.2008.09.006

Thomas, S., Reading, J., \& Shephard, R. J. (1992). Revision of the Physical-Activity Readiness Questionnaire (PAR-Q). Canadian Journal of Sport Sciences-Revue Canadienne Des Sciences Du Sport, 17, 338-345.

Vedul-Kjelsås, V., Sigmundsson, H., Stensdotter, K., \& Haga, M. (2012). The Relationship between Motor Competence, Physical Fitness and Self-Perception in Children. Child: Care, Health and Development, 38, 394-402. http://dx.doi.org/10.1111/j.1365-2214.2011.01275.x

Vicente-Rodríguez, G., Rey-López, J. P., Mesana, M. I., Poortvliet, E., Ortega, F. B., Polito, A., \& Moreno, L. A. (2012). Reliability and Intermethod Agreement for Body Fat Assessment among Two Field and Two Laboratory Methods in Adolescents. Obesity, 20, 221-228. http://dx.doi.org/10.1038/oby.2011.272

Videra-García, A., \& Reigal-Garrido, R. (2013). Autoconcepto físico, percepción de salud y satisfacción vital en una muestra de adolescentes. Analytical Psychology, 29, 141-147. 
Weiss, M. R., Mcauley, E., Ebbeck, V., \& Wiese, D. M. (1990). Self-Esteem and Causal Attributions for Children's Physical and Social Competence in Sport. Journal of Sport and Exercise Psychology, 12, 21-36.

Willows, N. D., Ridley, D., Raine, K. D., \& Maximova, K. (2013). High Adiposity Is Associated Cross-Sectionally with Low Self-Concept and Body Size Dissatisfaction among Indigenous Cree Schoolchildren in Canada. BMC Pediatrics, 12, 118. http://dx.doi.org/10.1186/1471-2431-13-118

Zulaika, L. M., \& Goñi, A. (2000). La participación en el deporte escolar y el autoconcepto en escolares de 10 a 11 años de la provincia de Guipúzcoa. Apunts: Educación física y deportes, 59, 6-10. 
Scientific Research Publishing (SCIRP) is one of the largest Open Access journal publishers. It is currently publishing more than 200 open access, online, peer-reviewed journals covering a wide range of academic disciplines. SCIRP serves the worldwide academic communities and contributes to the progress and application of science with its publication.

Other selected journals from SCIRP are listed as below. Submit your manuscript to us via either submit@scirp.org or Online Submission Portal.
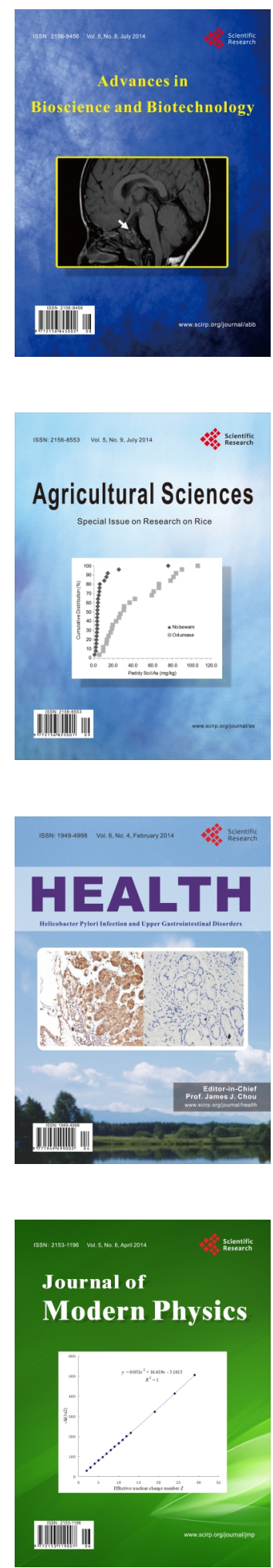
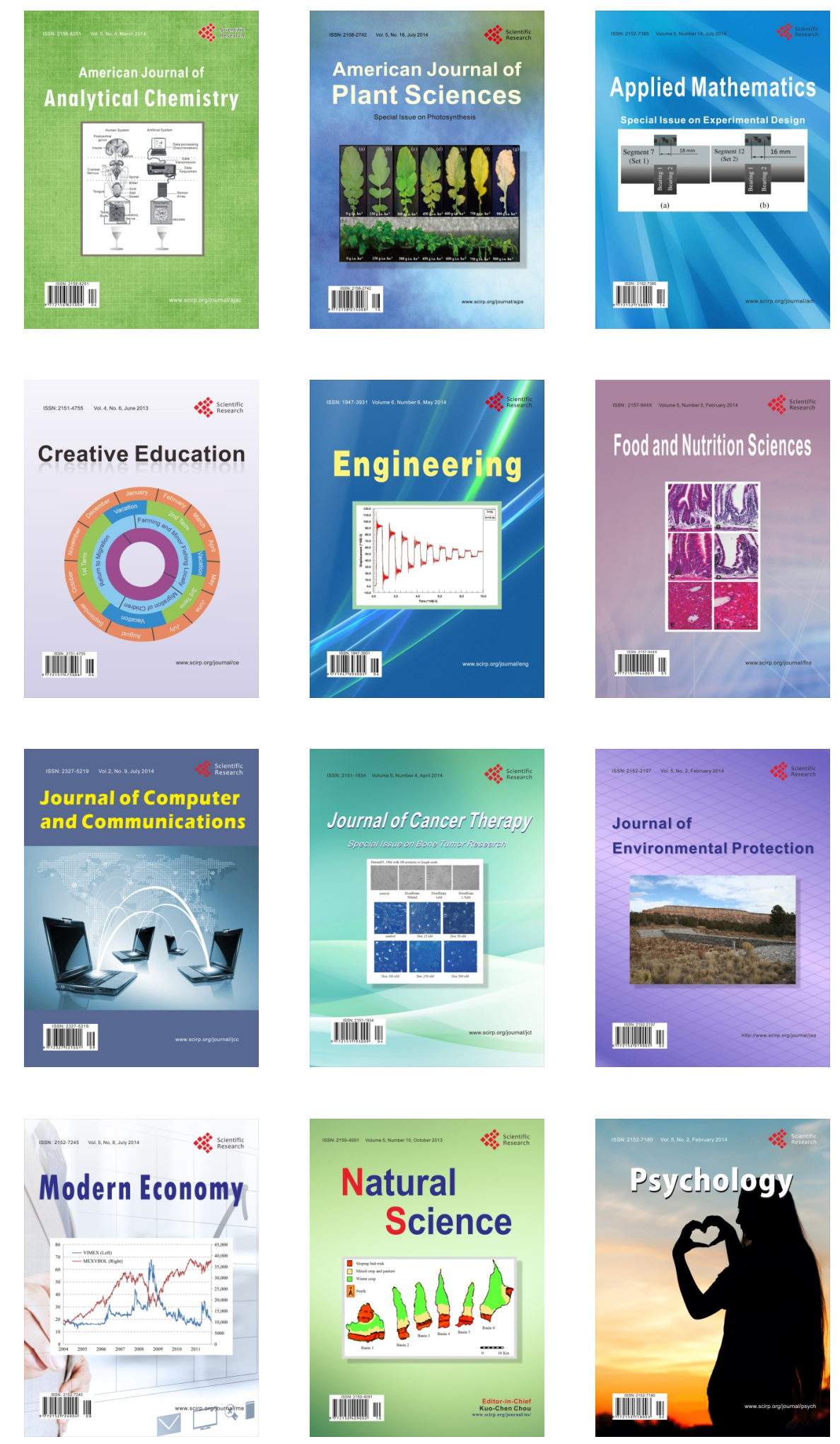